\title{
Hepatitis C: clinical and biological features related to different forms of cocaine use
}

\author{
Hepatite C: características clínicas e biológicas relacionadas \\ às diferentes formas de uso da cocaína
}

\author{
Silvia Bassani Schuch-Goi, Juliana Nichterwitz Scherer, Felix Henrique Paim Kessler, \\ Anne Orgler Sordi, Flavio Pechansky, Lisia von Diemen
}

\begin{abstract}
Introduction: Hepatitis C virus (HCV) infection is related with several liver diseases such as cirrhosis and hepatocellular carcinomas, leading to more than 0.5 million deaths every year and to a great global burden. It is known that injection drug users show a high prevalence of HCV infection, being considered a risk group for this disease. Cocaine users seem to be in greater risk than other drug users, and several hypotheses for this association are being studied.

Aim: To review data on $\mathrm{HCV}$ infection in cocaine users, taking into consideration the relevance of the different routes of drug administration and other risk behaviors.

Methods: This was a narrative review performed in the main scientific databases.

Results and conclusion: Data suggest that cocaine use could be associated with HCV infection due to the specificities of cocaine consumption pattern, even in those subjects who do not inject drugs, in addition to other risky behaviors, such as tattooing and unprotected sex. Injectable cocaine users seem to be more susceptible to contamination than users who do not inject drugs. However, evidence is pointing to the possibility of infection by sharing drug paraphernalia other than syringes. Moreover, specific immune system impairments caused by cocaine use are also being linked with HCV infection susceptibility, persistence and increased pathological effects.
\end{abstract}

Key words: HCV infection, cocaine, immune system, drug users, injection drugs, non-injection drugs.

\section{Resumo}

Introdução: $O$ vírus da hepatite $\mathrm{C}(\mathrm{HCV})$ está relacionado com graves patologias hepáticas, como a cirrose e o carcinoma hepatocelular, causando mais de meio milhão de mortes todos os anos, o que reflete um problema de saúde mundial. Sabe-se que usuários de drogas injetáveis possuem alta prevalência de infeç̧ão pelo HCV, sendo por isso considerados um dos maiores grupos de risco. Usuários de cocaína parecem ter maior risco de contrair o vírus do que usuários de outras drogas, e diversas hipóteses para essa associação estão sendo estudadas.

Objetivo: Revisar evidências de associação da infecção pelo HCV em usuários de cocaína, considerando a relevância das diferentes formas de administração da droga e comportamentos de risco.

Métodos: Esta foi uma revisão narrativa realizada nos principais bancos de dados científicos.

Resultados e conclusão: As evidências atuais sugerem que o uso de cocaína pode estar associado com a infecção por HCV devido às especificidades do padrão de consumo da droga, mesmo naqueles indivíduos que não fazem uso de drogas injetáveis, além de outros comportamentos de risco, como tatuagens e sexo desprotegido. Usuários de cocaína injetável parecem estar mais suscetíveis à contaminação do que usuários de cocaína não injetável. Entretanto, há a possibilidade de infecção devido ao compartilhamento de outros equipamentos de uso além das seringas (cachimbos, por exemplo). Além disso, prejuízos do sistema imune causados pela cocaína também parecem estar associados com a suscetibilidade de infecção pelo $\mathrm{HCV}$, além da manutenção e piora dos sintomas da doença.

Descritores: HCV, cocaína, sistema imune, uso de drogas, drogas injetáveis, drogas não-injetáveis.

Centro de Pesquisas em Álcool e Drogas, Centro Colaborador em Álcool e Drogas HCPA/SENAD, Hospital de Clínicas de Porto Alegre, Universidade Federal do Rio Grande do Sul (UFRGS), Porto Alegre, RS, Brazil.

Submitted Oct 24 2016, accepted for publication Jul 032017.

Suggested citation: Schuch-Goi SB, Scherer JN, Kessler FH, Sordi AO, Pechansky F, von Diemen L. Hepatitis C: clinical and biological features related to different forms of cocaine use. Trends Psychiatry Psychother. 2017;39(4):285-292. http://dx.doi.org/10.1590/2237-6089-2016-0076 


\section{Introduction}

Current data indicate that approximately 185 million people worldwide have been infected with hepatitis C virus (HCV), and that around 350,000 deaths occur each year due to all HCV-related causes. ${ }^{1}$ $\mathrm{HCV}$ infections account for a quarter of the cases of cirrhosis and primary liver cancer, ${ }^{2}$ representing a major contribution to end-stage liver disease. Only in Europe, estimations via HCV-attributable fractions indicate that HCV caused more than 86,000 deaths and 1.2 million disability adjusted life years (DALYs) in one year. Most of the DALYs (95\%) were accumulated by patients in preventable disease stages. ${ }^{3}$

Injection drug users (IDUs) are responsible for a major international public health problem, and they remain the largest group of persons infected with $\mathrm{HCV}^{4}$ Estimates indicate that there are about 16 million individuals who inject drugs worldwide, ${ }^{5}$ and unsafe drug paraphernalia is the main agent of virus transmission among users. Between 14 and 21 million people (0.3$0.5 \%$ of the population aged $15-64$ years) are cocaine users. ${ }^{6}$ Studies suggest that 10 million people who inject drugs are $\mathrm{HCV}$-infected worldwide, ${ }^{7}$ reflecting the high prevalence of these comorbidities.

Prevalence of $\mathrm{HCV}$ infection among non-injection drug users (NIDU), in turn, is much higher than in the general population. ${ }^{8,9} \mathrm{HCV}$ infection is more likely among older individuals and those with tattoos - factors previously associated with HCV infection -, and among those who share crack inhalation implements, ${ }^{8}$ probably because of the presence of HCV in intranasal drug users' nasal secretions. ${ }^{10}$

To facilitate evidence-based policymaking and promote better treatments, it is essential to estimate the impact of $\mathrm{HCV}$ infection in different populations, e.g., cocaine users. Our objective is to propose a review of $\mathrm{HCV}$ infection patterns among cocaine users. For that, it is important to understand the immunobiological changes that drugs cause in cells compromised by hepatitis, differentiate usage patterns and behavior among IDUs and NIDUs, and finally propose prevention strategies for this group of patients.

\section{HCV and cocaine immune system}

It is known that substance use affects several components of the immune system. Drug use can affect the immune system directly, through the activation of receptors on immune cells, or indirectly, acting in the central nervous system. This process interferes with the immune response mediated by antibodies and decreases the production of interleukins (ILs) and gamma interferon (IFN- $\gamma$ ). Depending of the type of substance, different effects are observed. ${ }^{11}$ As a result, substance use alters host immunity, which is related with an increased susceptibility to infections. ${ }^{11,12}$

Cocaine has multiple physiological and pharmacological mechanisms of action that could affect immune cell function and response, particularly because doses and duration of drug administration are varied. Pellegrino et al. showed that peripheral administration of cocaine resulted in a significant decrease in mitogeninduced lymphocyte proliferation. ${ }^{13}$ Cocaine-induced immunomodulation is a complex phenomenon with a range of enhancing and inhibitory pathways. ${ }^{14}$ It acts decreasing cytokine formation, lymphocyte proliferation, natural killer cell activity, as well as antibody formation and cellular hypersensitivity. ${ }^{11}$ Cocaine also exerts an indirect modulation of the immune system through the sigma-1 $(\sigma-1)$ receptor, expressed in the central and peripheral nervous system. ${ }^{15}$

HCV has been shown to bind to the dendritic cell immune system, even though viral replication within these cells occurs at a very low level. Dendritic cells from people with chronic HCV infection are impaired in their capacity to stimulate T cells. ${ }^{16}$ In chronic HCV infections, there is a reduction and dysfunction of blood dendritic cell subsets. ${ }^{17}$

There are several lines of evidence demonstrating the correlation between substance use and HCV infection. Morphine destabilizes IFN-mediated innate immunity and enhances HCV replication in human hepatocytes. ${ }^{18,19}$ Moreover, recent studies have shown that microRNAs (miRNAs) related with the HCV replication promotion process are increased in heroin users with HCV infection, while HCV-suppressive miRNA are downregulated. ${ }^{20}$ New studies have identified cocaine suppression of miRNAs associated with HIV infection, ${ }^{21,22}$ but no evidence has been reported regarding $\mathrm{HCV}$ infection and miRNA modulation by cocaine use so far. Although there are several studies investigating substance use and $\mathrm{HCV}$, there is a lack of studies that explores the specific mechanisms that concern cocaine use and $\mathrm{HCV}$ infection. Most of the research on cocaine and $\mathrm{HCV}$ are centered on individuals with HIV and report a faster progression to AIDS and decreasing CD4/ CD8 ratio. So far, evidence suggests that cocaine may induce suppression in lymphoproliferation by acting on receptors located in the periphery, therefore decreasing immune defenses and increasing viral load.12,15

HCV core protein promotes proliferation of human hepatoma cells via activation of nuclear factor kappa-B (NF-KB) - a major, inducible transcription factor whose modulation triggers a cascade of intracellular 
signaling events. ${ }^{23}$ Cocaine increases the expression of NF-KB p105 in mature dendritic cells, which may be associated with viral (e.g., HCV or HIV-1) persistence or increased pathological effects. Cocaine and HCV may act synergistically through their actions in monocytederived mature dendritic cells to interfere with the host's cellular defenses against the virus. ${ }^{24}$ Such alterations could suggest that cocaine use increases susceptibility to viral infections.

Few studies have shown alterations in HCV-infected cocaine users. We already know that other stimulants, such as methamphetamine (METH), inhibit intracellular IFN-a expression in human hepatocytes, which was associated with the increase in HCV replication. This is evidence that METH has the ability to compromise IFN-a-mediated innate immunity, thus promoting $\mathrm{HCV}$ replication in hepatocytes. ${ }^{25}$ When we consider only cocaine, in rats, chronic cocaine administration increased IL-10 and TNF-a production and had no effect on IL-1 and IFN-Y production. ${ }^{26}$

Taken together, the poor evidence by immunological control of $\mathrm{HCV}$ infection and its relationship with a stimulant drug like cocaine should lead researchers to seek the immunological components that might be involved in this association. Questions to address in the future include defining in more detail specific HCVrelated cell alterations among cocaine users.

\section{HCV and injecting cocaine use}

The most common documented route of $\mathrm{HCV}$ infection is through blood transfusions without previous screening and by sharing syringes among IDUs. ${ }^{27,28}$ Therefore, injecting cocaine users, similarly to other IDUs, are a major risk group to contract this infection. Notwithstanding, there is still little evidence regarding IDU and HCV contamination risk factors in this specific population, especially among cocaine users that do not use other psychoactive substances. Aceijas \& Rhodes reviewed data on HCV prevalence among IDUs worldwide and found reports of $\mathrm{HCV}$ prevalence rates of at least $50 \%$ among IDUs in 49 countries or territories. ${ }^{27}$

Overall, the prevalence of HCV infection in the IDU population varies greatly around the world, with midpoint reports ranging from 9.8 to $97.4 \% .^{7}$ There is evidence suggesting that the variation in prevalence and incidence observed between different populations could be explained by differences in cultural and ethnical aspects associated with stigma, discrimination, risk behaviors and/or access to health care, services and preventive education. ${ }^{29}$ Also, differences in prevalence rates seem to be gender- and age-specific among different DUI populations. ${ }^{30}$ Moreover, $\mathrm{HCV}$ is one of the infections most commonly identified among drug users - a recent systematic review suggested that about 10.0 million IDUs (range 6.0-15.2) were contaminated with HCV in 2010, which is 3.5 times higher than the estimate for HIV infection in the same population (2.8 million; range 0.8-6.2 million). ${ }^{7}$

One interesting study called HCV Synthesis Project, which is also a meta-analysis of studies of HCV epidemiology and prevention in drug users worldwide, examined data from 127 studies of IDUs that reported $\mathrm{HCV}$ prevalence rates in relation to age or year since onset of drug injection. That study reported that, even within the group of young users ( $<25$ years old), or within the group of recent users ( $<1-3$ years of use), the reported prevalence of HCV infection was equal or higher than $70 \%$. Moreover, the study suggested that there is a high risk of acquiring HCV shortly after onset of drug injection. This is very worrisome and may have implications for future prevention strategies, since recent drug users are less likely to search treatment and therefore receive educational and prevention information. ${ }^{30,31}$

One study with cocaine users found that injecting cocaine users are more likely to have HCV infection than those who deny injection practice. ${ }^{32}$ Similarly to general IDUs, higher family income, tattooing, sharing drug paraphernalia, history of drug use for more than 5 years, and daily use of substances of abuse were risk factors to HCV infection among cocaine users. ${ }^{32}$ There is also evidence that the sharing of materials for injection other than syringes/needles, like filters and rinse water, contribute substantially to the spread of hepatitis C among IDUs. ${ }^{33,34}$

Genotypes $1 \mathrm{a}$ and $3 \mathrm{a}$ predominate among IDUs, with genotype $3 a$ being far more frequent in IDUs than in the general population. ${ }^{35,36}$ In a study with Brazilian cocaine users, subtype 1 was most frequently found in the sample $(73.3 \%)$, although genotype 3 was also found $(26.7 \%)$, especially in injecting cocaine users $(13.3 \%){ }^{32}$ It is assumed that the presence of different genotypes can be due to characteristics such as the geography from which the infection was contracted, type of drug used (injectable or non-injectable), and multiple exposures to HCV infections. Genotype 3, for instance, is more common in European populations.

When comparing cocaine injection among heroindependent volunteers, participants who had injected cocaine during the previous month had a nine-fold greater risk of being HCV-positive compared to noncocaine users and those who used cocaine by a noninjecting route. ${ }^{37}$ In this same sample, the more frequently the participant used cocaine during the 
previous month, the greater their risk of being HCVpositive. This highlights the need for special care in relation to $\mathrm{HCV}$ in the primary attention of drug users when they also consume cocaine.

Several studies are showing a high prevalence of psychiatric comorbidities in IDUs. ${ }^{38-41}$ Even though we know that psychiatric comorbidities are very prevalent in drug users, it is very difficult to isolate the symptoms when the patient is in active use or with a short period of abstinence. Population studies show that the most prevalent disorders in this population are anxiety disorders, followed by mood disorders and personality disorders, especially antisocial personality disorders.

Personality traits or disorders as well as cognitive deficits could be an important issue to be addressed in this population. Personality disorders, e.g. borderline and antisocial, are associated with a greater likelihood of sharing injection equipment. ${ }^{42}$ Heroin IDUs with cognitive deficits are more likely to have a history of hepatitis $C$ infection, supporting the idea that cognitive factors may lead to increased risky behaviors and thus transmission of infections. ${ }^{43}$ Other personality trait disorders, such as negative temperament and disinhibition, impulsivity, sensation-seeking, novelty seeking and reward-sensitivity are frequently reported in drug users. ${ }^{43}$ In this sense, psychiatric disorders may occur before or during drug abuse and are also associated with physical comorbidity, including HCV infection, and its treatments. ${ }^{44}$

Taken together, existing estimates underline that HCV remains a great harm to the health of both injectors and former injectors, creating a substantial health burden worldwide. ${ }^{28} \mathrm{HCV}$-negative status may be representative of an established subgroup of safer injectors who have remained free of infection because of consistent safe injecting practices. ${ }^{45}$

\section{HCV and non-injecting cocaine use}

Research has mainly focused on injection drug use, but non-injecting cocaine users are also at greater risk of HCV infection. ${ }^{46}$ Several studies have reported higher $\mathrm{HCV}$ infection in this group in comparison to the general population, particularly among crack cocaine users. ${ }^{8,47}$ $\mathrm{HCV}$ prevalence among crack users varies greatly, from $1.4 \%{ }^{48}$ to around $50 \% .^{36}$ Intranasal cocaine users are not considered a risk group per se, but they could hide a route of parenteral virus spread. ${ }^{49}$ Even taking into account that some of them may not have reported drug injection in the past, HCV prevalence is higher than expected. ${ }^{8}$ Therefore, other potential HCV infection routes have been suggested among non-injecting cocaine users.
Sharing non-injection drug use paraphernalia is a plausible route for $\mathrm{HCV}$ transmission in this population. ${ }^{9}$ HCV RNA has already been detected in crack pipes, ${ }^{50}$ in nasal secretions and drug-sniffing implements of HCVinfected intranasal drug users, ${ }^{10,51}$ making this infection route biologically reasonable. Among crack users, oral burns or cuts are frequent, and sharing crack pipes is a common practice in the drug scene. ${ }^{52}$ Consistent with this, sharing a crack pipe has been associated with $\mathrm{HCV}$ infection among crack users. ${ }^{9,53,54}$ With regard to sharing snorting devices and HCV infection, evidence suggests an association. ${ }^{8,9}$ As inhaled cocaine users are not systematically tested, blood donor studies have raised most of the evidence. ${ }^{49,55,56}$ In a recent study with HCV-infected blood donors, intranasal cocaine use was an independent risk factor, and most of them $(86 \%)$ reported shared use of snorting devices. ${ }^{49}$ Additionally, a high level of nasal pathology can be detected in intranasal cocaine users, such as erosion in nasal mucosa, rhinitis, septum perforation, loss of nasal hairs, all of which can increase the infection risk. ${ }^{51}$

Sexual transmission of $\mathrm{HCV}$ is much less efficient than HBV and HIV. ${ }^{57}$ However, some sexual risk groups show increased HCV prevalence with no other parenteral risk factor reported. ${ }^{58,59}$ Other concomitant sexually transmitted diseases with genital erosive lesions or traumatic sexual intercourse seems to enhance sexual transmission of HCV. ${ }^{60}$ Indeed, multiple sexual partners, drug use in the course of sex, exchanging sex for drugs or money have been reported to increase the risk of HCV infection. ${ }^{47,61-63}$ In fact, both crack and intranasal cocaine users show levels of high sexual risk behavior, especially the former. ${ }^{47,64}$ Sexually transmitted diseases are frequent among female crack cocaine users exchanging sex for drugs or money, as well as in those who have multiple sexual partners, making them a vulnerable group for HCV infection. 64,65 Accordingly, among non-injecting cocaine users, women crack cocaine users have the highest prevalence rates of $\mathrm{HCV}$ infection, reaching almost $60 \%$ in some samples. ${ }^{47,65}$

Tattooing and piercing as risk factors for $\mathrm{HCV}$ infection have conflicting findings in the literature. ${ }^{66}$ The increase in risk infection seems to be related to highrisk groups, when tattoos are applied in prison settings or by friends ${ }^{66}$ - both practices are commonplace among drug users. ${ }^{54}$ In addition, drug users are more likely not to receive tattoos or piercings in professional parlors, and the prevalence of these characteristics can reach more than $30 \%$ for tattoos and more than $40 \%$ for piercings. ${ }^{54,67}$

Collectively, these findings suggest that these nonparenteral routes of $\mathrm{HCV}$ infection add a small risk 
each one. Nonetheless, non-injecting cocaine users are exposed to multiple high-risk situations, placing them in a major group of risk.

\section{Prevention}

Many countries in Europe may not yet have invested sufficiently in studies or surveillance systems to guide HCV treatment and prevention policies for IDUs. ${ }^{68,69}$ In other countries, such as Canada, decreases in HCV incidence were accompanied by increases in crack cocaine smoking, and decreases in syringe borrowing coincided with a scale-up of harm reduction programs. ${ }^{70}$

Despite the progress made in the development of HCV vaccines, ${ }^{71}$ we still do not have an effective vaccine. Primary prevention against hepatitis $C$ focuses on reducing risks of infection through safe injections, and blood safety remains the best alternative to reduce morbidity and mortality. ${ }^{1}$

Page et al. recently reviewed some HCV prevention strategies. The results demonstrated that efforts to reduce exposure to $\mathrm{HCV}$ in people who inject drugs must incorporate reduction of sharing drug preparation equipment. Besides, tests to identify acute HCV in the "window period" may aid in prevention, because this is a period with high viremia, during which individuals may not know that they are positive and may have a high risk of HCV transmission. ${ }^{71}$

Significant advances have been made in preventing HIV infection among injectors, but we still know little about preventing hepatitis $\mathrm{C}$. Both prevalence and incidence of hepatitis $C$ can remain high among IDUs even in the context of widespread implementation of harm reduction programs. ${ }^{72}$ The main impact on prevention is a reduced risk of infection through sharing syringes and needles. This may be possible with the distribution of new and sterile needles and through orientation of individuals on the use of disinfected equipment for the manufacture and use of drugs, ${ }^{73}$ in addition to the promotion of interventions for abstinence from substance use. Indicated interventions include motivational techniques, contingency management, specialized outpatient clinics, support groups, harm reduction and, depending on the severity and associated risks, hospitalization.

Improvement in mental health conditions, including the treatment of psychiatric comorbidities and psychoeducation about the disorders, is also very important when considering prevention strategies for any health outcome among drug users. For example, both drug use and HCV infection have independently been associated with depression and suicidality. ${ }^{74,75}$
When overlooking these high-risk groups, evidence suggests a high prevalence of comorbidities among drug users with HCV. ${ }^{76}$ In this sense, suicide ideation, psychological morbidity and other psychiatric symptoms have been shown to be associated with HCV status and with IFN-a treatment. ${ }^{75}$ In fact, suicide was the second most reported cause of death among a sample of HCVpositive drug users in a 33-year follow-up study. ${ }^{76}$ Therefore, special attention should be given to HCVpositive users through prevention strategies and routine assessment as part of a comprehensive approach to prevention and care.

The last strategy is to promote HCV treatment. Current therapeutic advances are transforming chronic $\mathrm{HCV}$ into a routinely curable disease. HCV detection combined with the availability of simple, well-tolerated treatment regimens ${ }^{77}$ is an alternative to reduce virus infection in substance users.

Studies covering prevention strategies in NIDUs are still scarce, probably due to the evidence of inconsistency on the main routes of transmission. It is known that warning about the risks of sexual transmission is an important measure, since this is a vulnerable population to unprotected sex and drugs used as currency. Bertoni et al. showed that a large proportion of women reported involvement in sex-for-drug exchanges. ${ }^{78}$

Hepatitis C prevention counselling and education are intended to increase knowledge of the disease, clarify perceptions about vulnerability to infection, and increase personal capacity for undertaking safer behaviors. As with syringe sharing, the sharing of drug preparation equipment was associated with lower perceived benefits of safer injecting but also with low self-efficacy to convince others to inject more safely. Interventions should aim to heighten awareness of the benefits of risk reduction, and to provide IDUs with the skills necessary to negotiate safer injection practices with their peers. ${ }^{79}$

Among illicit drug users attending inner city clinics in Canada, studies have observed a low uptake of HCV treatment, but a high willingness to receive therapy. ${ }^{80}$ An increased focus on improving education about the long-term consequences of $\mathrm{HCV}$ and the availability of effective treatment are important components for expanding HCV treatment among illicit drug users. ${ }^{72}$ This means guidance on risk behavior, prevention of sexually transmitted diseases, interventions on violence and crime approach, plus psychoeducation about substance use disorders and psychiatric comorbidities such as mood disorders, anxiety disorders and personality disorders.

It is relevant to point out that some authors suggest that heroin and cocaine users with cognitive deficits are more likely to have a history of hepatitis 
$B$ and/or C infection, supporting the idea that cognitive factors may lead to higher rates of risky behaviors and thus transmission of infection. ${ }^{42,81}$ They suggest that identification and evaluation of cognitive impairment should be considered among individuals with substance use disorders. Individuals with such conditions who abuse drugs may be at an increased risk of infectious diseases and may struggle to succeed in treatment programs. The findings highlight the need for adaptations that can be made to this potentially large subpopulation of drug users.

\section{Conclusion}

Evidence shows that cocaine use is associated with increased risk for HCV contamination. The main aspects that have been raised to explain this association are the main forms of administration of cocaine (injection, aspiration and inhalation) and other risky behaviors that are frequently perceived in these drug users. Injectable cocaine users seem to be more likely to contamination than users who do not inject drugs. However, because of the right prevalence of HCV in non-injecting cocaine users, evidence has been pointing to possibility of contamination through the sharing of drug paraphernalia other than syringes.

Other risk behaviors for contamination, like unprotected sex and tattooing, are also highly observed in this population. It is also important to consider that the use of cocaine leads to considerable immunosuppression, which also favors viral infections. Specific impairments in the immune system caused by cocaine use, such as an increased expression of NF$\mathrm{KB}$, are also linked with $\mathrm{HCV}$ infection susceptibility, persistence and increased pathological effects. When we take this evidence into account, it seems apparent that cocaine users are a major risk group for HCV contamination. However, more studies are necessary in order to understand the specific risk factors of cocaine consumption in regards to HCV.

\section{Disclosure}

No conflicts of interest declared concerning the publication of this article.

\section{References}

1. Mohd Hanafiah K, Groeger J, Flaxman AD, Wiersma ST. Global epidemiology of hepatitis $C$ virus infection: new estimates of age-specific antibody to HCV seroprevalence. Hepatology. 2013:57:1333-42.

2. Perz JF, Armstrong GL, Farrington LA, Hutin YJ, Bell BP. The contributions of hepatitis $B$ virus and hepatitis $C$ virus infections to cirrhosis and primary liver cancer worldwide. J Hepatol. 2006;45:529-38.

3. Muhlberger N, Schwarzer R, Lettmeier B, Sroczynski G, Zeuzem S, Siebert U. HCV-related burden of disease in Europe: a systematic assessment of incidence, prevalence, morbidity, and mortality. BMC Public Health. 2009;9:34.

4. De P, Roy E, Boivin JF, Cox J, Morissette C. Risk of hepatitis C virus transmission through drug preparation equipment: a systematic and methodological review. J Viral Hepat. 2008;15:279-92.

5. Mathers BM, Degenhardt L, Phillips B, Wiessing L, Hickman M, Strathdee SA, et al. Global epidemiology of injecting drug use and HIV among people who inject drugs: a systematic review. Lancet. 2008;372:1733-45.

6. Degenhardt L, Hall W. Extent of illicit drug use and dependence, and their contribution to the global burden of disease. Lancet. 2012;379:55-70.

7. Nelson PK, Mathers BM, Cowie B, Hagan H, Des Jarlais D, Horyniak $D$, et al. Global epidemiology of hepatitis B and hepatitis C in people who inject drugs: results of systematic reviews. Lancet. 2011;378:571-83.

8. Scheinmann R, Hagan H, Lelutiu-Weinberger C, Stern R, Des Jarlais DC, Flom PL, et al. Non-injection drug use and Hepatitis C Virus: a systematic review. Drug Alcohol Depend. 2007;89:112.

9. Tortu S, McMahon JM, Pouget ER, Hamid R. Sharing of noninjection drug-use implements as a risk factor for hepatitis C. Subst Use Misuse. 2004;39:211-24.

10. McMahon JM, Simm M, Milano D, Clatts M. Detection of hepatitis $C$ virus in the nasal secretions of an intranasal drug-user. Ann Clin Microbiol Antimicrob. 2004;3:6.

11. Friedman $H$, Pross $S$, Klein TW. Addictive drugs and their relationship with infectious diseases. FEMS Immunol Med Microbiol. 2006;47:330-42.

12. Kaushik KS, Kapila K, Praharaj AK. Shooting up: the interface of microbial infections and drug abuse. J Med Microbiol. 2011;60:408-22.

13. Pellegrino TC, Dunn KL, Bayer BM. Mechanisms of cocaine-induced decreases in immune cell function. Int Immunopharmacol. 2001; 1:665-75.

14. Kubera M, Filip M, Basta-Kaim A, Nowak E, Siwanowicz J, Zajicova $A$, et al. The effect of cocaine sensitization on mouse immunoreactivity. Eur J Pharmacol. 2004;483:309-15.

15. Friedman $\mathrm{H}$, Newton $\mathrm{C}$, Klein TW. Microbial infections, immunomodulation, and drugs of abuse. Clin Microbiol Rev. 2003; 16:209-19.

16. Pachiadakis I, Pollara G, Chain BM, Naoumov NV. Is hepatitis C virus infection of dendritic cells a mechanism facilitating viral persistence? Lancet Infect Dis. 2005;5:296-304.

17. Kanto $T$, Inoue $M$, Miyatake $H$, Sato A, Sakakibara M, Yakushijin $\mathrm{T}$, et al. Reduced numbers and impaired ability of myeloid and plasmacytoid dendritic cells to polarize $\mathrm{T}$ helper cells in chronic hepatitis C virus infection. J Infect Dis. 2004;190:1919-26.

18. Li $Y$, Zhang T, Douglas SD, Lai JP, Xiao WD, Pleasure DE, et al. Morphine enhances hepatitis $\mathrm{C}$ virus (HCV) replicon expression. Am J Pathol. 2003;163:1167-75.

19. Wang CQ, Li Y, Douglas SD, Wang X, Metzger DS, Zhang T, et al. Morphine withdrawal enhances hepatitis $C$ virus replicon expression. Am J Pathol. 2005;167:1333-40.

20. Zhou Y, Sun L, Wang X, Zhou L, Li J, Liu M, et al. Heroin use promotes HCV infection and dysregulates HCV-related circulating microRNAs. J Neuroimmune Pharmacol. 2015;10:102-10.

21. Napuri J, Pilakka-Kanthikeel S, Raymond A, Agudelo M, YndartArias A, Saxena SK, et al. Cocaine enhances HIV-1 infectivity in monocyte derived dendritic cells by suppressing microRNA-155. PLoS One. 2013;8:e83682.

22. Mantri CK, Pandhare Dash J, Mantri JV, Dash CC. Cocaine enhances HIV-1 replication in CD4+ T cells by down-regulating MiR-125b. PLoS One. 2012;7:e51387.

23. Sato Y, Kato J, Takimoto R, Takada K, Kawano Y, Miyanishi K, et al. Hepatitis $C$ virus core protein promotes proliferation of human hepatoma cells through enhancement of transforming growth factor alpha expression via activation of nuclear factor-kappaB. Gut. 2006;55:1801-8.

24. Reynolds JL, Mahajan SD, Aalinkeel R, Nair B, Sykes DE, Schwartz SA. Proteomic analyses of the effects of drugs of abuse 
on monocyte-derived mature dendritic cells. Immunol Invest. 2009;38:526-50.

25. Ye L, Peng JS, Wang X, Wang YJ, Luo GX, Ho WZ. Methamphetamine enhances Hepatitis $C$ virus replication in human hepatocytes. J Viral Hepat. 2008; 15:261-70.

26. Kubera M, Filip M, Budziszewska B, Basta-Kaim A, Wydra K, Leskiewicz $M$, et al. Immunosuppression induced by a conditioned stimulus associated with cocaine self-administration. J Pharmacol Sci. 2008;107:361-9.

27. Aceijas C, Rhodes T. Global estimates of prevalence of HCV infection among injecting drug users. Int J Drug Policy. 2007;18:352-8.

28. Alter MJ. Epidemiology of hepatitis C virus infection. World J Gastroenterol. 2007;13:2436-41.

29. Lelutiu-Weinberger C, Pouget ER, Des Jarlais DD, Cooper HL, Scheinmann R, Stern R, et al. A meta-analysis of the hepatitis $C$ virus distribution in diverse racial/ethnic drug injector groups. Soc Sci Med. 2009;68:579-90.

30. Hagan H, Des Jarlais DC, Stern R, Lelutiu-Weinberger C, Scheinmann R, Strauss S, et al. HCV synthesis project: preliminary analyses of $\mathrm{HCV}$ prevalence in relation to age and duration of injection. Int J Drug Policy. 2007;18:341-51.

31. Miller CL, Johnston C, Spittal PM, Li K, Laliberté N, Montaner JS, et al. Opportunities for prevention: hepatitis $C$ prevalence and incidence in a cohort of young injection drug users. Hepatology. 2002;36:737-42.

32. Oliveira-Filho AB, Sawada L, Pinto LC, Locks D, Bahia SL, Castro $J A$, et al. Epidemiological aspects of $H C V$ infection in non-injecting drug users in the Brazilian state of Para, eastern Amazon. Virol J. 2014;11:38.

33. Pouget ER, Hagan $H$, Des Jarlais DC. Meta-analysis of hepatitis C seroconversion in relation to shared syringes and drug preparation equipment. Addiction. 2012;107:1057-65.

34. Mathei C, Shkedy Z, Denis B, Kabali C, Aerts M, Molenberghs $G$, et al. Evidence for a substantial role of sharing of injecting paraphernalia other than syringes/needles to the spread of hepatitis $\mathrm{C}$ among injecting drug users. J Viral Hepat. 2006;13:560-70.

35. Webster G, Barnes E, Brown D, Dusheiko G. HCV genotypes--role in pathogenesis of disease and response to therapy. Baillieres Best Pract Res Clin Gastroenterol. 2000;14:229-40.

36. Mahfoud Z, Kassak K, Kreidieh K, Shamra S, Ramia S. Distribution of hepatitis $C$ virus genotypes among injecting drug users in Lebanon. Virol J. 2010;7:96.

37. Roux $P$, Fugon L, Jones JD, Comer SD. Hepatitis C infection in nontreatment-seeking heroin users: the burden of cocaine injection. Am J Addict. 2013;22:613-8.

38. Erfan S, Hashim AH, Shaheen M, Sabry N. Effect of comorbid depression on substance use disorders. Subst Abus. 2010;31:1629.

39. Gu J, Lau JT, Chen $\mathrm{H}$, Chen X, Liu C, Liu J. Mental health and interpersonal factors associated with HIV-related risk behaviors among non-institutionalized female injection drug users who are also sex workers in China. Women Health. 2010;50:20-36.

40. Gu J, Lau JT, Chen $\mathrm{H}$, Tsui $\mathrm{H}$, Ling W. Prevalence and factors related to syringe sharing behaviours among female injecting drug users who are also sex workers in China. Int J Drug Policy. 2011:22:26-33.

41. Jones DL, Waldrop-Valverde D, Gonzalez P, Mack A, Kumar AM, Ownby R, et al. Mental health in HIV seronegative and seropositive IDUs in South Florida. AIDS Care. 2010;22:152-8.

42. Severtson SG, Mitchell MM, Hubert A, Latimer W. The relationship between performance on the Shipley Institute of Living Scale (SILS) and hepatitis $C$ infection among active injection drug users in Baltimore, Maryland. Am J Drug Alcohol Abuse. 2010;36:615.

43. Hopwood CJ, Morey LC, Skodol AE, Sanislow CA, Grilo CM, Ansell $E B$, et al. Pathological personality traits among patients with absent, current, and remitted substance use disorders. Addict Behav. 2011;36:1087-90.

44. Iskandar S, Kamal R, De Jong CA. Psychiatric comorbidity in injecting drug users in Asia and Africa. Curr Opin Psychiatry. 2012;25:213-8.

45. Morissette C, Cox J, De P, Tremblay C, Roy E, Allard R, et al. Minimal uptake of sterile drug preparation equipment in a predominantly cocaine injecting population: implications for HIV and hepatitis C prevention. Int J Drug Policy. 2007;18:204-12.

46. Jauffret-Roustide $M$, Le Strat $Y$, Couturier E, Thierry D, Rondy $M$, Quaglia $M$, et al. A national cross-sectional study among drug-users in France: epidemiology of $\mathrm{HCV}$ and highlight on practical and statistical aspects of the design. BMC Infect Dis. 2009;9:113.

47. Shannon K, Rusch M, Morgan R, Oleson M, Kerr T, Tyndall MW. $\mathrm{HIV}$ and HCV prevalence and gender-specific risk profiles of crack cocaine smokers and dual users of injection drugs. Subst Use Misuse. 2008;43:521-34.

48. Sa LC, Araujo TM, Griep RH, Campelo V, Monteiro CF. Seroprevalence of hepatitis $C$ and factors associated with this in crack users. Rev Lat Am Enfermagem. 2013;21:1195-202.

49. Allison RD, Conry-Cantilena C, Koziol D, Schechterly C, Ness P, Gibble J, et al. A 25-year study of the clinical and histologic outcomes of hepatitis $\mathrm{C}$ virus infection and its modes of transmission in a cohort of initially asymptomatic blood donors. J Infect Dis. 2012;206:654-61.

50. Fischer B, Powis J, Firestone Cruz M, Rudzinski K, Rehm J. Hepatitis $C$ virus transmission among oral crack users: viral detection on crack paraphernalia. Eur J Gastroenterol Hepatol. 2008;20:29-32.

51. Aaron S, McMahon JM, Milano D, Torres L, Clatts M, Tortu S, et al. Intranasal transmission of hepatitis $C$ virus: virological and clinical evidence. Clin Infect Dis. 2008;47:931-4.

52. Faruque S, Edlin BR, McCoy CB, Word CO, Larsen SA, Schmid DS, et al. Crack cocaine smoking and oral sores in three innercity neighborhoods. J Acquir Immune Defic Syndr Hum Retrovirol. 1996;13:87-92.

53. Howe CJ, Fuller CM, Ompad DC, Galea S, Koblin B, Thomas D, et al. Association of sex, hygiene and drug equipment sharing with hepatitis $C$ virus infection among non-injecting drug users in New York City. Drug Alcohol Depend. 2005;79:389-95.

54. Macias J, Palacios RB, Claro E, Vargas J, Vergara S, Mira JA, et al. High prevalence of hepatitis $C$ virus infection among noninjecting drug users: association with sharing the inhalation implements of crack. Liver Int. 2008;28:781-6.

55. Conry-Cantilena C, VanRaden M, Gibble J, Melpolder J, Shakil AO, Viladomiu $L$, et al. Routes of infection, viremia, and liver disease in blood donors found to have hepatitis C virus infection. N Engl J Med. 1996;334:1691-6.

56. Vivas-Arceo C, Benavides SA, De Jesus Trujillo J, Panduro A, RivasEstilla AM. Hepatitis C virus: prevalence and routes of infection among blood donors of West Mexico. Hepatol Res. 2003;25:11523.

57. Terrault NA, Dodge JL, Murphy EL, Tavis JE, Kiss A, Levin TR, et al. Sexual transmission of hepatitis $C$ virus among monogamous heterosexual couples: the HCV partners study. Hepatology. 2013;57:881-9.

58. Cavlek TV, Margan IG, Lepej SZ, Kolaric B, Vince A. Seroprevalence, risk factors, and hepatitis $\mathrm{C}$ virus genotypes in groups with highrisk sexual behavior in Croatia. J Med Virol. 2009;81:1348-53.

59. Inciardi JA, Surratt HL, Kurtz SP. HIV, HBV, and HCV infections among drug-involved, inner-city, street sex workers in Miami, Florida. AIDS Behav. 2006;10:139-47.

60. Tohme RA, Holmberg SD. Is sexual contact a major mode of hepatitis C virus transmission? Hepatology. 2010;52:1497-505.

61. Booth RE, Kwiatkowski CF, Chitwood DD. Sex related HIV risk behaviors: differential risks among injection drug users, crack smokers, and injection drug users who smoke crack. Drug Alcohol Depend. 2000;58:219-26.

62. Tull MT, Gratz KL, Weiss NH. Exploring associations between borderline personality disorder, crack/cocaine dependence, gender, and risky sexual behavior among substance-dependent inpatients. Personal Disord. 2011:2:209-19.

63. Terrault NA. Sexual activity as a risk factor for hepatitis C. Hepatology. 2002;36:S99-105.

64. Duff $P$, Tyndall M, Buxton J, Zhang R, Kerr T, Shannon K. Sexfor-Crack exchanges: associations with risky sexual and drug use niches in an urban Canadian city. Harm Reduct J. 2013;10:29.

65. von Diemen L, De Boni R, Kessler F, Benzano D, Pechansky F. Risk behaviors for HCV- and HIV-seroprevalence among female crack users in Porto Alegre, Brazil. Arch Womens Ment Health. 2010;13:185-91.

66. Tohme RA, Holmberg SD. Transmission of hepatitis $C$ virus infection through tattooing and piercing: a critical review. Clin Infect Dis. 2012;54:1167-78.

67. Campollo O, Roman S, Panduro A, Hernandez G, Diaz-Barriga $L$, Balanzario MC, et al. Non-injection drug use and hepatitis $\mathrm{C}$ among drug treatment clients in west central Mexico. Drug Alcohol Depend. 2012;123:269-72.

68. Xue J, Zhu $H$, Chen $Z$. Therapeutic vaccines against hepatitis $C$ virus. Infect Genet Evol. 2014;22:120-9. 
69. Wiessing L, Ferri M, Grady B, Kantzanou M, Sperle I, Cullen KJ, et al. Hepatitis $C$ virus infection epidemiology among people who inject drugs in Europe: a systematic review of data for scaling up treatment and prevention. PLoS One. 2014;9:e103345.

70. Grebely J, Lima VD, Marshall BD, Milloy MJ, DeBeck K, Montaner $\mathrm{J}$, et al. Declining incidence of hepatitis $C$ virus infection among people who inject drugs in a Canadian setting, 1996-2012. PLoS One. 2014;9:e97726.

71. Page $K$, Morris MD, Hahn JA, Maher $L$, Prins $M$. Injection drug use and hepatitis $C$ virus infection in young adult injectors: using evidence to inform comprehensive prevention. Clin Infect Dis. 2013;57 Suppl 2:S32-8.

72. Mateu-Gelabert P, Treloar C, Calatayud VA, Sandoval M, Zurian JC, Maher $L$, et al. How can hepatitis $C$ be prevented in the long term? Int J Drug Policy. 2007;18:338-40.

73. Shaheen MA, Idrees $M$. Evidence-based consensus on the diagnosis, prevention and management of hepatitis $C$ virus disease. World J Hepatol. 2015;7:616-27.

74. Grebely J, Dore GJ. What is killing people with hepatitis C virus infection? Semin Liver Dis. 2011;31:331-9.

75. Schaefer M, Capuron L, Friebe A, Diez-Quevedo C, Robaeys G, Neri $S$, et al. Hepatitis $C$ infection, antiviral treatment and mental health: a European expert consensus statement. J Hepatol. 2012;57:1379-90.

76. Kielland KB, Skaug K, Amundsen EJ, Dalgard O. All-cause and liver-related mortality in hepatitis $C$ infected drug users followed for 33 years: a controlled study. J Hepatol. 2013;58:31-7.
77. Kohli A, Shaffer A, Sherman A, Kottilil S. Treatment of hepatitis C: a systematic review. JAMA. 2014;312:631-40.

78. Bertoni N, Burnett C, Cruz MS, Andrade T, Bastos FI, Leal E, et al. Exploring sex differences in drug use, health and service use characteristics among young urban crack users in Brazil. Int J Equity Health. 2014;13:70.

79. Cox J, De P, Morissette C, Tremblay C, Stephenson R, Allard R, et al. Low perceived benefits and self-efficacy are associated with hepatitis $\mathrm{C}$ virus (HCV) infection-related risk among injection drug users. Soc Sci Med. 2008;66:211-20.

80. Grebely J, Genoway KA, Raffa JD, Dhadwal G, Rajan T, Showler $G$, et al. Barriers associated with the treatment of hepatitis $C$ virus infection among illicit drug users. Drug Alcohol Depend. 2008;93:141-7.

81. Severtson SG, Hedden SL, Martins SS, Latimer WW. Patterns of Cognitive Impairments Among Heroin and Cocaine Users: The Association With Self-Reported Learning Disabilities and Infectious Disease. J Learn Disabil. 2010.

\section{Correspondence:}

Lisia von Diemen

Centro de Pesquisas em Álcool e Drogas

Centro Colaborador em Álcool e Drogas HCPA/SENAD

Hospital de Clínicas de Porto Alegre, Universidade Federal do Rio

Grande do Sul

Rua Professor Álvaro Alvim, 400

90420-020 - Porto Alegre, RS - Brazil

Tel.: +55 51 3359-6488

E-mail: lisiavd@gmail.com 